\title{
Rédai Dorottya
}

Független kutató

\section{Roma lányok szexualitása tanár-szemmel Etnikai- és osztályegyenlőtlenségek diszkurzív újratermelődése a középiskolában}

\begin{abstract}
A 2019-ben megjelent könyvem alapjául szolgáló kutatásban a nem, a szexualitás, az etnicitás és a társadalmi osztály interszekcióit vizsgáltam egy magyarországi középiskolában, etnográfiai módszerekkel. Arra kerestem a választ, hogy a szexualitás iskolai diszkurzusai hogyan artikulálják a diákok nemi, etnikai és osztály-hovatartozását és ezzel együtt hogyan reprodukálják a társadalmi egyenlőtlenségeket a középfokú oktatás intézményes keretein belül. Ebben a tanulmányban tanárokkal készült interjúrészletek segítségével szeretném bemutatni, hogyan elemezhetőek azok a gender/szexualitás diszkurzusok, amelyek etnikai és egyben osztály-kategóriákat hoznak létre. A bemutatott interjúrészletekben tanárok beszélnek a diákok szexualitásáról és a szexualitáson keresztül jelölik ki egyértelműen a diákok helyét az iskolai etnikai és osztályhierarchiában. Ez a két kategória nemcsak metszi egymást, hanem konvergál, egymás nélkül nem értelmezhető ezekben a diszkurzusokban. Az interszekcionális elemzések gyakran két szubjektum-kategória metszéspontjára fókuszálnak. Elemzésemben kísérletet teszek annak megvizsgálására, hogy mi történik ott, ahol több ilyen szubjektum-kategória diszkurzívan összetalálkozik, és ennek nagyon is materiális következményei lesznek. ${ }^{1}$
\end{abstract}

\section{Bevezető}

Ebben a tanulmányban megvizsgálom, hogy miként elemezhetőek azok a gender és szexualitás diszkurzusok, amelyekben etnikai és osztály-kategóriák artikulálódnak, illetve, hogy miként termelődnek újra a társadalmi egyenlőtlenségek ezekben a diszkurzusokban. A kvalitatív diszkurzuselemzéshez a doktori kutatásomhoz 2009-2011-ben végzett középiskolai terepmunkám során készített interjúk átirataiból használok fel részleteket. A vizsgált iskola egy kombinált szakiskola-szakközépiskolagimnázium, amelyben a kutatás idején kb. 1000 diák tanult, kétharmaduk a

${ }^{1}$ Ez a tanulmány az Exploring Sexuality in Schools. The intersectional Reproduction of Inequality címú, a Palgrave Macmillan kiadásában 2019-ben megjelent monográfiám alapján készült; közléséhez a Kiadó hozzájárult. 
szakiskolában, egynegyedük a szakközépiskolában, és 10\%-uk a gimnáziumban. A diákok többsége alsó-középosztálybeli, illetve munkásosztálybeli háttérből jött, és becslésem szerint kb. 20\%-uk volt cigány vagy cigány-magyar származású és kb. 80\%-uk fehér magyar származású. ${ }^{2}$

A terepmunkám során szexuális nevelés és más órákat figyeltem meg, kiscsoportos (3-4 fős), félig strukturált interjúkat készítettem kb. 90 diákkal, valamint egyéni interjúkat öt tanárral, a védőnővel és az iskolaigazgatóval. Az interjúkról hangfelvételeket készítettem, amelyeknek az átiratait használom fel az elemzéshez. A tanulmányban szereplő idézetek az interjú átiratokból származnak. Az interjúalanyok álnéven szerepelnek.

A tanulmányban egyaránt használom a „roma” és a „cigány” kifejezéseket. A roma származású diákokra cigányként utalok, a nem roma származásúakra pedig magyarként. Ezek etnikai kategóriák, nem az állampolgárságra utalnak, hiszen minden interjúalany magyar állampolgár volt. A cigány származású diákok nem használták magukra a roma megnevezést, így ezt a szót inkább akkor használom, amikor a hivatkozott szakirodalomban ezt használja a szerző, vagy amikor általánosságban utalok erre az etnikumra. Természetesen az etnikai önbesorolás rendkívül összetett jelenség, amelyet máshol részletesen megvitatok (Rédai 2019; 2016; lásd még: Neményi \& Vajda 2014, Neményi 2007), itt viszont nem térek ki erre a kérdésre, terjedelmi okokból. Használom a fehér/fehér magyar kifejezéseket is, amikor a magyar származású interjúalanyoknak a romákhoz való többségi hatalmi viszonyulására utalok.

\section{Elméleti keretek}

\section{Performativitás és a szubjektumok diszkurzív artikulációja}

A szubjektumok diszkurzív artikulálódásának elemzésében arra a Foucault-i értelmezésre támaszkodom, amely szerint a szubjektum a diszkurzusok produktív hatalmán keresztül artikulálódik, és ezért a diszkurzusok nemcsak tükrözik a társadalmi viszonyokat, hanem alakítják is azokat (Foucault 1999; 1980). Butler performativitás-elmélete szerint a szubjektumok a performatív beszédaktusok teremtő hatalma következtében artikulálódnak (Butler 2001; 2005), méghozzá interszekcionálisan, vagyis a

2 A diákok etnikai hovatartozását illegális nyilvántartani, így a saját becslésemre hagyatkozom, amely alapjául az interjúalanyok ön-identifikációja, valamint a diákok és tanárok becslései szolgálnak. Könyvemben részletesen megvitatom a diákok etnikai ön-identifikációjának komplexitását (Rédai 2019, 201-204). 
nemi, szexuális, etnikai és osztály-identitások metszéspontjában. ${ }^{3}$ Butler szerint a társadalmi nem beszédaktusok stilizált ismétlődésén keresztül jön létre, nem pedig egy már eleve adott, „,eredeti” társadalmi nem létezik. Ez a folyamatos ismétlés teret ad arra, hogy a társadalmi nem egy állandó kategóriának értelmeződjön, de arra is, hogy a beszédaktusok időnként ne az eredeti szándék szerint „süljenek el”, hanem új, szubverzív szubjektumokat hozzanak létre (Butler 2005). Azért tartom fontosnak e diszkurzusok kritikai elemzését (lásd: Mills 1997), mert ezekben nemi, osztály- és etnikai különbségek artikulálódnak, és ezek az artikulációk nemcsak diszkurzív események, hanem a maguk szintjén hozzájárulnak a nagyon is materiális társadalmi egyenlőtlenségek konstruálásához és újratermeléséhez.

Butler performativitás-elméletét elsősorban a társadalmi nem és a szexualitás konstrukciójára építette fel, de az elméleti alapvetései jól alkalmazhatóak az etnikai és az osztály-szubjektumok artikulálódásának elemzésére is (lásd: Rédai 2019). Horváth Kata (2008) ezt az elméletet használja, kritikát fogalmazva meg azzal szemben, hogy a köznyelvi és a tudományos gondolkodás egyaránt már eleve adottnak tekinti a „cigányság” kategóriáját. Ezzel szemben ő azt állítja, hogy a „cigány” mint kategória a cigányok és magyarok közötti különbségtétel müködésében artikulálódik.

Ez az állítás a cigányt elsődlegesen nem mint társadalmi vagy kulturális csoportot, identitást, mint diszkurzív vagy társadalmi kategóriát, mint hatalmi elrendezések vagy társadalmi kényszerek termékét jeleníti meg. Ezeket az „intézményeket” a múködésben létrejövő, abban megerősödő, esetleg kikristályosodó jelenségként lehet esetleg meglátni, semmiképp sem a működésektől függetlenül leírható (azokat megelőző vagy azok termékeként létrejött) entitásokként. [...] [H]a bármilyen kontextusban „előkerül a cigány”, az biztosan különbségtétel lesz. Tehát a különbségtétel mechanizmusait vizsgálva a cigánykonstruáló helyzetek és kontextusok értelmezhetőek. (2008, 2-3).

Sajnos ez a - véleményem szerint fontos és új elemzési perspektívát hozó - szöveg ma már nem elérhető online, és nem is nem nyert teret ezidáig a roma identitásról szóló magyar - főként szociológiai megközelítésű elemzésekben a performativitás-elmélet és a szubjektumok diszkurzív artikulálódásának vizsgálata. Ebben a szövegben felveszem ezt a fonalat és a cigányság mint szubjektum artikulálódásának működését próbálom tetten érni és megmutatni, hogy a kisebbségi csoportok hátrányos helyzetének materiális aspektusaival összefüggésben lényeges vizsgálni azt, hogy maguk a

${ }^{3}$ Ezt az elméleti keretet részletesebben kifejtem a TNTeF egy korábbi számában közölt írásomban, különösen az etnicitás, a nem és a szexualitás interszekciójára fókuszálva (Rédai 2016). 
csoportkategóriák hogyan artikulálódnak, mivel diszkurzív szinten a kategóriák artikulálódása teszi lehetôvé az általuk megjelenített társadalmi csoportok közötti egyenlőtlenségek újratermelődését.

\section{Faj/rassz vs. etnicitás és fehérség}

A magyar szociológiában a „fehérség” vagy „fehérbőrűség” (whiteness) koncepciója mindmáig kevéssé van használatban. Míg a rasszizmus fogalma a rassz-alapú diszkriminációt és erőszakot teszi láthatóvá, a fehérség fogalma a - szintén rassz-alapú - hegemón fehér pozíció privilegizáltságát, azaz láthatatlanságát és jelöletlenségét mutatja meg egy posztkolonialista keretben. Junghaus (2011) szerint ,[a]mennyiben a posztkoloniális teoretikai keret nélkül próbáljuk leírni az európai romák jelenlegi helyzetét, amit konzerválunk az a „cigánykérdés”, vagyis a 'Gypsy problem'-ez az a diskurzus, amely úgy építi fel a romák által megélt problémákat (mint például a munkanélküliség, a szegénység, és a társadalmi kirekesztés más manifesztációi) mint saját cigány kultúrájuk eszencializált melléktermékét”. A fehérség láthatatlan norma, amely többnyire csak indirekt módon, valami ellentéteként jelölődik, és ez része a fehérség által gyakorolt elnyomó hatalom múködésének (Nakayama \& Krizek 1999). Jó példa erre az a magyar szociológiában és a közbeszédben egyaránt elterjedt dichotóm etnikai megnevezés, ami romákra/cigányokra és nem romákra/nem cigányokra osztja a két - nagyon is heterogén - társadalmi csoportot. Ezáltal a fehér magyarok nem neveződnek meg fehérként, hanem a cigányság tagadásaként, fehérségükből adódó hatalmi pozíciójuk így láthatatlan normává válik a cigányságról szóló diszkurzusokban. A fehérség e láthatatlan normája a továbbiakban elemzett interjúrészletekben is megjelenik.

A tanulmányban az „etnicitás” és „etnikai” kifejezéseket használom elemzési kategóriaként. A magyar cigányság jelölésére ez a szociológiában, szakpolitikában és a köznyelvben bevett kifejezés. Megoldatlan dilemma számomra, hogy mi lenne az a megnevezés, amely láthatóvá tenné, hogy a cigányságról szóló diszkurzusokban keverednek és együttélnek a különböző nézőpontok, amelyek a cigányságot nem csak etnikai jellemzők alapján kategorizálják. A magyarországi cigányokat ugyanis a többségi diszkurzusokban egyszerre tekintik saját kultúrával rendelkező csoportnak (etnikum), valamint jellegzetes fizikai és jellembeli sajátosságokkal rendelkező csoportnak (rassz/faj). Utóbbira utalnak például az olyan közbeszédben gyakori kifejezések, mint ,a cigányoknak a vérében van...” vagy „,nem az idén barnult". Tóth Kinga Dóra (2004) kutatása megmutatja, hogy van egy harmadik kategória is, a réteg vagy szociális státusz. Vizsgálatából kiderül, hogy a magyarországi cigányok általában etnikumként vagy szociális jellemzők (azaz osztály-státusz) alapján határozzák meg önmagukat, a fehér magyarok 
pedig inkább (vélt vagy valós) faji (rasszbéli) és/vagy szociális kritériumok alapján határozzák meg, hogy kit tekintenek cigánynak. A fajjal/rasszal szemben az etnicitás rugalmasabb kategória és kulturális konnotációi vannak (Waters 1990). Ugyanakkor az etnikai (vagy szociális státusz-) alapú önbesorolást sok esetben felülírja a többség általi - hatalmi viszonyok kontextusában történő - kategorizálás (Rédai 2019; Neményi \& Vajda 2014), amely jellemzően rasszbéli vagy szociális alapon történik, tehát az etnikai besorolásban előkerülnek a faji/rassz alapú és osztály-elemek is.

Felmerül tehát, hogy pontosabb lenne-e a „faj/etnikum” vagy „rassz/etnikum” illetve „faji/etnikai” vagy „rasszbéli (rassz-alapú)/etnikai” szóösszetételek használata, hasonlóan az angol „race/ethnicity”, „racial (raced)/ethnic" használatához. Már csak azért is, mivel ebben a tanulmányban a cigányságról szóló fehér hegemón diszkurzusokra fókuszálok a kritikai rasszelmélet (critical race theory) megközelítéséből (lásd pl. Delgado \& Stefancic 2001), nem a cigány interjúalanyok önidentifikációjára (erről lásd: Rédai 2019; 2016). A „faj” szó itt az angol „race” magyar megfelelőjeként értendő, ahogyan pl. Federmayer Éva (2019) is használja, természetesen nem rendszertani értelemben, hanem kritikai elemzési kategóriaként, hasonlóan a „gender/társadalmi nem” kategóriájához. A „faj” és a „rassz” ebben az értelmezésben szinonímák. Amint Federmayer rávilágít, a „faj” szó „[...] eszközként alkalmazva - a kritikai rasszelmélet gondolkodási/kritikai kategóriájaként - segíti a leplezett rasszista gyakorlatok és intézmények felismerését és tanulmányozását" (2019, 46).

Mint Imre Anikó (2005) megállapítja, a kelet-európai politikai és szociológiai diszkurzusokban a „faj” (race) szó továbbra is tabu és többnyire az „etnicitás” szóval helyettesített. Bár vannak érthető történelmi és elvi okai a „faj” vagy „rassz” kifejezések kerülésének, de a megnevezés hiányában láthatatlanná vagy kevésbé jelentőssé válnak a romák - mint az egyetlen szignifikáns magyarországi etnikai kisebbség - ellen elkövetett, illetve intézményesített megnyilvánulások, cselekedetek, közpolitikák, diszkrimináció és erőszak rasszista motivációi. Ennek ellenére a magyar tudományos szóhasználatról kevés kritikai reflexió áll rendelkezésre; úgy túnik, hallgatólagos megegyezés van arról, hogy az „etnikai” egyben „faji” és (a szintén tabusított szóhasználattal) „osztály” elemeket is magában hordoz. Ez utóbbi miatt a legpontosabb megnevezés a „faj/etnikum/osztály” lenne, viszont ez egy „emészthetetlen” szóösszetételnek tűnik, legfeljebb rövidített formában működhetne (pl. FEO), hasonlóan az LMBTQ-hoz. Mivel semmiképpen nem szeretném azt sugallni, hogy a három kategória összemosható vagy szinoníma, ezért a „FEO” használatát mégsem javasolnám. Dilemmám viszont továbbra is megoldatlan marad, ugyanakkor az interjúrészletek elemzésénél megmutatom, hogyan artikulálódnak és 
konvergálnak e három kategória elemei diszkurzív szinten, egy adott szubjektum és egyben társadalmi pozíció meghatározásánál.

\section{Társadalmi osztály}

Bourdieu (1984) a kulturális tôke fogalmával írja le, hogyan termelődnek újra a társadalmi osztályok közti egyenlőtlenségek az oktatásban. A kulturális tőke felhalmozása nagyban múlik a család már meglévő kulturális és gazdasági tőkéjén. A kulturális tőke, hasonlóan a gazdasági tőkéhez, egyenlőtlenül oszlik el a társadalomban. Bourdieu és Passeron (1992, 10-11) szerint a kulturális tőke csak azok számára hozzáférhető, akik már eleve fel vannak szerelve a domináns társadalmi osztályok értékeit, nézőpontjait, meggyőződéseit, ideológiai és gazdasági elköteleződéseit tükröző tananyag dekódolásához szükséges nyelvi és kulturális tőkével. Így az elvben semleges és mindenki számára egyenlően hozzáférhető, de valójában kulturális tőkefüggő tudás átadásával az oktatási intézmények hozzájárulnak a kulturális tőke osztály-alapú elosztásának újratermelődéséhez és a meglévő társadalmi hierarchia konzerválásához.

Lareau és Weininger (2003) a kulturális tőkét „mikro-interakciós folyamatokként” definiálják, „amelyek által az egyének stratégikus tudásfelhasználása, készségei és kompetenciái találkoznak a tudásértékelés intézményesített standardjaival" (2003, 569; saját fordítás). Bourdieu-re hivatkozva azt állítják, hogy az oktatási rendszer úgy termeli újra a kulturális tőke társadalmi elosztását, hogy azoknak az osztályoknak az oktatási normáit veszi értékelési kritériumnak, amelyek ezeket a normákat rá tudják kényszeríteni a rendszerre (2003, 578-579). Ezzel a megközelítéssel jól megfogható, hogy mi történik a vizsgált (vagy bármely más hasonló) iskolában: középosztálybeli tanároknak - és a középosztályt támogató oktatáspolitikának - hatalmában áll elöírni az intézményesült oktatás standardjait a közép- és munkásosztálybeli diákok számára. Miközben e normák szerint értékelik a tanárok a diákokat - amelyeknek a középosztálybeli diákok jobban meg tudnak felelni, a munkásosztálybeliek viszont kevésbé -, fenntartják az osztály-alapú megkülönböztetéseket és reprodukálják az osztály-alapú hierarchiát, amely által egyben a saját osztály-pozíciójukat is megerösítik.

A társadalmi osztály vitatott vagy került fogalom a magyar szociológiában; gyakrabban használják a szociológusok a „szocio-ökonómiai státusz” vagy a „társadalmi rétegzettség” fogalmakat. Egyúttal gyakran használatos a szociális helyzeten keresztüli megközelítés a cigányság definiálására (Tóth 2004), amely által gyakorlatilag a cigányság osztálykategóriaként jelenik meg. Ezek a szociális státusz-alapú megközelítések 
azonban nem foglalják magukban az osztálypozíció kulturális aspektusait. Beverley Skeggs (1997; 2004) kulturális megközelítést használ, amelyben az osztályt olyan szimbolikus rendszernek tekinti, amely - együtt más szimbolikus rendszerekkel - testekre írja egy adott kultúra összetevőit, mintha azok személyes tulajdonságok lennének. Elemzésében megmutatja, hogy történelme van annak, ahogyan az osztálypozíciót a szexualitás morális diszkurzusain keresztül olvassák rá testekre (2004, 3, 85-90). Ebben a tanulmányban szándékaim szerint rávilágítok, hogyan íródik rá ebben az iskolában az osztály-státusz és az etnikai hovatartozás a roma diákok testére a szexualitás diszkurzusain keresztül. Elemzésemben alapvetően kulturális megközelítésből vizsgálom a társadalmi osztály fogalmát, de összekapcsolom a materiális megközelítéssel, hogy láthatóvá váljanak a diszkurzív megkülönbözetések nagyon is materiális szocio-ökonómiai következményei.

\section{Társadalmi reprodukció az iskolában}

Az iskola hierarchikus intézmény, amely a társadalmi egyenlőtlenségeket egyszerre enyhítheti, újratermelheti, sôt, erősítheti is (lásd: Downey \& Condron 2016). Olyan hely, ahol az egyének hatalmi viszonyok mentén rendeződő hierarchikus mintákban helyezkednek el, egy tágabb társadalmi berendezkedést mintázva, amelyben a társadalmi csoportok közötti különbség egyben a kevésbé privilegizált vagy kevesebb hatalommal rendelkező csoportok alárendeltségét, hátrányos megkülönböztetését, elnyomását és kirekesztését is jelenti. E megkülönböztetés többek között a társadalmi nem, a társadalmi osztály, az etnikum és a szexualitás tengelyei mentén jelenik meg.

Magyarországon szelektív iskolarendszer érvényesül, amelyben a különböző középiskola-típusok különböző végzettségeket, és azzal összefüggésben különböző továbbtanulási, illetve munkapiaci esélyeket kínálnak. A szakiskola-szakközépiskola-gimnázium közötti hierarchia e komplex iskola falain belül is megjelent, miután itt mind a három típus jelen volt egy intézményen belül. Amint azt számos hazai és nemzetközi tanulmány bizonyítja, az erősen szelektív iskolarendszerek növelik a tanulási teljesítmények közti egyenlőtlenséget és súlyosbítják a diákok szocioökonómiai státuszából származó hátrányokat (Hermann-Kopasz 2018). Pfeffer (2008) szerint az oktatási mobilitás az ilyen rendszerekben alacsony. A szülők iskolázottsága is jelentősen befolyásolja az iskolatípus-választást, és így a szelektív iskolázási rendszer reprodukálja a családból hozott iskolázottsági mintákat (Kogan et al. 2012; Horn 2009; Berényi et al. 2008). Mint azt a 2018as (Oktatási Hivatal 2019) és korábbi PISA jelentések megmutatják, Magyarország azon országok közé tartozik, ahol a tanulók szociális, gazdasági 
és kulturális háttere különösen erősen befolyásolja a tanulók iskolai teljesítményét, és ezáltal reprodukálja a családjuk társadalmi pozícióját (Berényi et al. 2008).

Liskó (2008) szerint a szelektív magyarországi iskolarendszerben a rendszerváltás óta a hátrányos szocio-ökonómiai hátterű fiatalok körében megduplázódott a szakiskolában tanulók aránya, és közöttük a roma származású tanulók felülreprezentáltak. E tendencia tovább erősödött a 2010es években: míg a 2000-es évek elején a roma fiatalok kétharmada szerzett szakiskolai végzettséget (Liskó 2008, 96), 2015-ben a középiskolai végzettséget megszerzô roma fiataloknak a háromnegyede végzett szakiskolát (KSH 2016). A középiskolai lemorzsolódás is egyre növekszik a roma diákok körében: míg a magyar diákok között ez az arány 9\% körül mozgott a 2010es évek elején, a roma diákok körében 48\% volt (Hajdú et al. 2014, 27). A már eleve hatalmas különbség romák és magyarok között azután tovább nőtt: 2015-ben - a tankötelezettségi korhatár 18-ról 16 évre csökkentése után három évvel - a magyaroknál maradt 9\%, a romáknál viszont 60\%-ra emelkedett (KSH 2016). Amint ezek a kutatások megmutatják, az etnicitás és a társadalmi osztály metszi egymást, újratermeli a társadalmi egyenlőtlenségeket és meghatározza a fiatalok jövőbeli társadalmi-gazdasági státuszát és társadalmi mobilitását. Ezért tartom fontosnak beemelni az „osztály” fogalmát az oktatáskutatásba.

Egy olyan társadalmi rendszerben, amely hatalmi egyenlőtlenségek mentén szerveződik, a társadalmi kategóriák megkülönböztetése (mint pl. nő/férfi, cigány/magyar) egyben azok hierarchikus egymás alá/fölé rendelését is jelenti. Az iskola központi intézmény a gyerekek és fiatalok életében; olyan tér, ahol rengeteg idôt töltenek együtt, és folyamatosan performatív aktusokban pozicionálják magukat és egymást. Így a szubjektumok artikulálása és a társadalmi egyenlőtlenségek újratermelése összekapcsolódik az iskolában.

\section{Az iskolai hierarchia}

A vizsgált iskola élelmiszeripari szakmákhoz kínált képesítést és fő profilja a szakiskolai képzés volt, de volt szakközépiskolai és gimnáziumi képzés is, valamint felsőfokú technikusképzés. ${ }^{4}$ Noha lehetőség volt a szakiskolai végzettség megszerzése után leérettségizni, az igazgató elmondása szerint ezt csak a diákok kb. 20\%-a tette meg ebben az iskolában. A roma diákok erôsen túlreprezentáltak voltak a szakiskolában és alulreprezentáltak a gimnáziumban, és körükben az iskola-elhagyási arány magasabb volt, mint a

4 A jelenlegi iskolatípus-rendszerben az iskola szakgimnázium és szakiskolaként működik, felsőfokú technikus képzéssel. A gimnáziumi tagozat megszűnt 2012-ben. 
magyar diákok körében, az iskolaigazgató becslése szerint. A különböző képzéstípusok közti hierarchia érezhető volt a diákok körében, illetve abban, ahogy a tanárok kezelték a diákokat. A tanárok között is megvolt ugyanez a hierarchia: legmagasabban a gimnáziumi tanárok álltak, akik közismereti tantárgyakat tanítottak, utánuk jöttek az elméleti szakmai tárgyakat tanító szaktanárok, utánuk pedig a gyakorlati szakmai ismereteket tanító szakoktatók, akik nem feltétlenül rendelkeztek pedagógusi végzettséggel. Az iskola komplex hierarchikus viszonyrendszerét részletesen elemzem a könyvemben (Rédai 2019). Ebben a tanulmányban csak a diákok tanárok által diszkurzívan kijelölt pozíciójával foglalkozom.

A diákok iskolatípus szerinti kategorizálása és az egyenlőtlenségek diszkurzív újratermelése az intézmény minden szintjén folyik, a hivatalos dokumentumoktól a hétköznapi beszédmódokig. Az iskola 2008-as Pedagógiai Programja (PP) ${ }^{5}$ szerint, amely kutató munkám idején használatban volt, a diákok összetétele „nagyon heterogén”, „a tanulók kb. 50\%-a él csonka családban”. Míg a gimnáziumi és szakközépiskolai hallgatók stabilabb családi háttérrel és magasabb iskolai végzettségű szülőkkel rendelkeznek, a szakiskolás diákok esetében „,[a]z elvált szülők mellett igen gyakori, hogy egyik szülő elhalt, a másik nagyon nehéz körülmények között neveli gyermekét. A tanulók viszonylag magas százalékára igaz, hogy ha papírforma szerint van is mögötte gondviselö, gyakorlatilag szinte az egész életterületén magára van utalva.” A dokumentum szerint sok a „hátrányos helyzetű, köztük roma származású diák” az iskolában. A különböző diákok „neveltségi szintje” összefügg a szülői háttérrel és nagyon különböző: a gimnazista és szakközepes diákok szintje általában magasabb, viszont a diákokra a „szakiskolai célú osztályokban alacsony neveltségi szint a jellemző. Ezekben az osztályokban sokszor az alapvető normákkal sincsenek tisztában a tanulók." Tanulási motivációik is különbözőek a PP szerint: míg a gimnazistákat jobban érdeklik az elméleti tárgyak, a szakközepeseket és szakiskolásokat inkább a gyakorlati tárgyak érdeklik és kevésbé szeretnek tanulni.

Az idézett állítások megfogalmazásukban egy középosztálybeli intellektuális elitista hozzáállást tükröznek. Ahogy Reay (2006) rámutat, széles körben elterjedt egy olyan hibáztató diszkurzus, amely a munkásosztályt

\footnotetext{
${ }^{5}$ Az alábbi idézetek az iskola 2008-as pedagógiai programjából származnak, amelynek nem adom meg az elérhetőségét, az iskola anonimitásának megőrzése érdekében. Megjegyzem, az iskola legújabb, 2019-es Pedagógiai Programja már egész más nyelven íródott, inkább a tanulási-nevelési problémák és megoldásuk objektívabb, tanuló-központúbb, nem értékítéleteken alapuló leírása a jellemző rá, és kihangsúlyozza az egyenlő tanulási esélyek megteremtésének szándékát. Viszont a „csonka család” kifejezés ebben az alaposan átdolgozott programban is szerepel.
} 
kulturális deficitekkel bíró csoportnak tekinti, és ezeket a deficiteket teszi felelőssé a munkásosztálybeli fiatalok iskolai alulteljesítéséért. Ez a diszkurzus a munkásosztályt vagy áldozatként, vagy valamilyen formában hiányosságokkal rendelkezőként állítja be, és többnyire a családi otthont tekinti az osztály-tipikus gyakorlatok reprodukciós helyszínének $(2006,397)$. A 2008-as Pedagógiai Programban a „,neveltségi szint” udvarias kifejezés annak megjelölésére, hogy az adott tanulók milyen mértékig múveltek vagy müveletlenek, és azt sugallja, hogy a PP a szüleik iskolázottsági szintje alapján kategorizálja a diákokat alacsony vagy magas „neveltségi szintűként”. Az interjúkban gyakran használták tanárok a „neveltségi” vagy „szocializációs szint" kifejezést, és mindig a család kontextusában, mintha ők nem vettek volna aktívan részt a diákok nevelésében/szocializációjában. A nem kielégítő tanulási motivációra utaló állítás is a középosztálybeli entellektüel nézőpontról és a „munkásosztálybeli deficit” megközelítésről árulkodik: a diákokat kellene, hogy érdekeljék a tudományos közismereti tantárgyak, mint az irodalom, a történelem, a matematika, stb. Az a megállapítás, hogy a szakközepes és szakiskolás diákok ebből a szempontból ,alulteljesítenek”, mert inkább a gyakorlati tárgyak érdeklik őket, mutatja ennek a középosztálybeli normaképző pozíciónak a merevségét. Elvégre miért is lenne probléma, hogy egy olyan iskolában, ahol a diákok 90\%-a kétkezi szakmát tanul, inkább a gyakorlati, szakmai tárgyak érdeklik őket?

Az iskolaigazgató szerint a diákok etnikai arányai különböztek a különböző iskolatípusokban: a kb. 30 fös osztályokban a szakiskolában 6-7 roma diák volt, a szakközépiskolai osztályokban 1-2, a gimnáziumot pedig nem is említette. Úgy vélte, a különbség a tudásháttérben és a tanulási motivációkban rejlik:

Valószínű, hogy eleve olyan tudásháttérrel érkeznek, hogy a szakközépiskolát esélyük nincsen megcélozni. A szakiskolában sem azért ülnek, meggyőződésem szerint, mert - persze tisztelet a kivételnek - annyira tanulni akarnak, hanem mert tankötelezettség létezik, és be kell jönni az iskolába.

Az igazgató itt rávilágít a romák és magyarok, és egyben a különböző szocio-ökonómiai hátterű fiatalok különböző foglalkoztatási esélyeire (lásd: Hajdú et al. 2014). A (többszörösen) hátrányos helyzetű diákok valószínúleg nem a legjobb színvonalú általános iskolai oktatásban részesültek, a szegénység, az oktatáshoz való rossz hozzáférés, a nem támogató családi háttér (Csapó et al. 2009; Liskó 2008), valamint a romák esetében a nagyfokú iskolai szegregáció miatt (Kertesi \& Kézdi 2009). A kutatásom idején a roma fiatalok 48\%-ának nem volt középfokú végzettsége, 28\%-uknak volt szakiskolai végzettsége, $16 \%$ szakközépiskolát végzett, és 8\% gimnáziumot 
(Hajdú et al. 2014, 15). Noha a magyar, általános iskolát befejezett tanulók 99\%-a és a romák 95\%-a kezdett továbbtanulni középfokú intézményekben, a lemorzsolódási arányok jelentősen különböztek, és ezzel az általános iskolai szakadék tovább tágult a középiskolában (Hajdú et al. 2014, 13-14).

\section{„Egyfajta kultúra” - osztálykülönbségnek tünő etnikai különbségek (és fordítva) konstruálása a szexualitáson keresztül}

A roma és magyar diákok közti, az iskolarendszer szintjén megjelenő egyenlőtlenségek áttekintése után a tanulmány további részében olyan diszkurzusokat elemzek, amelyekben a diákok faji/etnikai és osztályszubjektumát tanárok artikulálják azáltal, hogy a diákok szexualitásának valamely aspektusáról beszélnek.

$\mathrm{Az}$ interjúban az iskolaigazgató azzal érvelt, hogy a szakiskolás diákoknak nem olyan a szexuális kultúrája, mint az elit gimnáziumokba járókénak. Amikor megkérdeztem, mit ért ez alatt, elmesélte, hogy a szakiskolai diákok indiszkrét módon használják az iskola tereit arra, hogy a szexualitásukat megéljék, például nem bújnak el a félig-meddig elfedett lépcsőfordulóba csókolózni, hanem beállnak a folyosó közepére és kerülgetni kell őket. Ennek oka szerinte az, hogy:

Hát, korábban érnek, és valószínű, hogy azért a szakképzésbe ma már olyan gyerekek jönnek - sajnos el lehet mondani, nem egy nagy öröm, de tény, hogy nem a legműveltebb gyerekek jönnek. Ez egyfajta kultúrát hoz magával, és itt most nem a romákra gondolok, hanem úgy általában. Valószínú, hogy ezért is jelenik meg ez. Mert lehet, hogy ha ez egy elit gimnázium, akkor egészen másképp kezelik a dolgot. (Iskolaigazgató, interjú)

Szerinte az iskola terének felhasználása a szexualitás megélésére ahhoz kapcsolódik, hogy a diákok manapság „korábban érnek”, mint régebben azaz korábban kezdenek aktív szexuális életet élni, és hogy „nem a legmúveltebb” háttérből jönnek. Mint korábban megvitattam, a szülők iskolázottsági szintje erősen befolyásolja, hogy a gyerekeik milyen iskolatípust választanak - már ha egyáltalán van választásuk: a leghátrányosabb helyzetú gyerekek mennek legnagyobb arányban szakiskolába. Az igazgató összekapcsolja a családi és iskolázottsági hátteret a szexuális viselkedéssel, és határvonalat húz a szakiskolás diákok és egy elitgimnázium elképzelt tanulói között. Véleménye szerint a szakiskolásoknak van egy olyan szexuális kultúrája, amely nem elfogadható egy középosztálybeli értékekre épülő intézményben. Ahogy Lupton és Hempel-Jorgensen állítja, „,[...] az iskolákat a középosztálybeli normák által befolyásolt iskolai viszonyokról és 
folyamatokról alkotott elképzelések alapján tervezik és támogatják" (2012, 610; saját fordítás). Ezeket a normákat az elit gimnázium diákjai képviselik, nem a szakiskolás tanulók, akik egy más fajta, kevésbé „legitim kultúrát” (lásd: Bourdieu 1984) hoznak be az iskolába.

„Nem a romákra gondolok” - teszi hozzá gyorsan. Tanárokkal való beszélgetéseim során megfigyeltem, hogy a hivatalos tanári beszédmódban az etnikai alapú különbségtétel tabu volt. Több tanár fontosnak tartotta hangsúlyozni, hogy nem látnak különbséget cigány és magyar diákok között, inkább az iskolatípus az, ami meghatározza a viselkedésüket. Ugyanakkor, nem egészen véletlenül, a romák aránya a szakiskolás osztályokban volt a legmagasabb. Azáltal, hogy az igazgató megerősíti, hogy nem a romákat érti a „más szexuális kultúrájú” diákok alatt, hanem a szakiskolás diákokat, „kifehéríti” a roma diákokat, az etnikai különbségtételt elrejti a „munkásosztálybeli kultúra” takarója alá. Ugyanakkor különbséget tesz aközött, amit Skeggs „,tiszta fehérnek” és „,piszkos fehérnek” nevez (2004, 91). Ezek a (ki)fehér(itett) szakiskolások egy másfajta fehérbőrűséget képviselnek, mint az elitgimnazisták, munkásosztálybeli „,kultúrájuk” miatt, amelynek része az eltúlzott és vulgáris szexuális viselkedés (lásd: Skeggs 2004, 100-102), ami szembehelyezkedik az iskolában elvárt tisztelettudó viselkedés középosztálybeli normájával. Ily módon, abbéli igyekezetében, hogy a diákokat ne etnikai hovatartozásuk, hanem „,kultúrájuk” és az iskolatípus szerint kategorizálja, az igazgató két különböző fehér csoportot konstruál, akik olyan osztály-hierarchiában állnak egymással, ami az etnikai hierarchiához hasonlít.

A továbbiakban megvizsgálom, hogyan reprodukálják a tanárok diszkurzusokon keresztül az osztály, faji/etnikai és nemek közti egyenlőtlenségeket, amikor cigány lányokról beszélnek. A tanárok fehér középosztálybeli diszkurzusában az etnikum és az osztály konvergál, a cigány diákoknak tulajdonított etnikai alapú kulturális értékek és viselkedések egyben az érintett diákok és tanárok osztály-pozícióját is kijelölik.

\section{„Kulturáltsági fok” - egy alacsonyabb osztály-státuszú cigány lány szubjektum artikulálása}

A következő interjúrészletben Anna, a felzárkóztató osztály ${ }^{6}$ osztályfőnöke „cigány lány” szubjektumot artikulál, miközben reprodukciós mintákról beszél:

\footnotetext{
${ }^{6}$ Terepmunkám idején indult minden évben egy ún. felzárkóztató osztály, általános iskolát még be nem fejezett, de már középiskolás korú (többnyire 15-16 éves), halmozottan hátrányos helyzetủ és/vagy komoly tanulási nehézségekkel küzdő fiatalok számára. Az osztály
} 
Igen-igen, tehát a [cigány] lányok ugye nagyon korán elhálnak. Valamilyen módon ugye ezzel gyakorlatilag nagykorúsítják ezeket a lányokat, ebből következik, [...] hogy ezeknek a lányoknak nem az lesz az első számú feladatuk az életben, hogy valamelyik pékségben dolgozzanak, hanem hogy gyerekeket szüljenek hosszú-hosszú időn keresztül. [...] Erre készíti fel a család, ezt várja tőlük a közvetlen környezet. [...] egyelőre ameddig jár a családi pótlék, addig járnak iskolába, de hát onnantól kezdve elsősorban nem az oktatás... [...] Hát, ha nagyon szigorú lennék, akkor azt mondanám, hogy [...] egy megélhetési forma az, hogy minél több gyermeket szüljenek, mert annál nagyobbak a támogatottságok, másrészt meg hát egy biológiai rendszer, ezen a kulturáltsági fokon biológiai elvárás és biológiai rendszer. [...] Ha a magasan kvalifikált, egyetemet végzett fiatalok között keresgélünk, akkor a sok osztályt, sok iskolát [végzett], nagy olvasottsággal, nagy rálátással lévő európai ember vagy észak-amerikai ember, az nem szül tizenöt évesen, mert ő elvárja, önmagától is, hogy csak akkor szül gyereket, ha a gyereknek külön szobája van, saját autójával tudja vinni az orvoshoz és ötszázezer forintot tud odaadni egy babakocsiért. [...] 27, 28, 3035 évesen első gyermeket vállalni nem is akkora kunszt. Náluk nincsenek ilyen [...] társadalmi elvárások. Egy feh... bocsánat, szóval egy nem roma, [ha] már a harmadik gyereket fölvállalja egy család, akkor már ránéznek: „Miből fogják eltartani?” „De jól megy nekik, hogy a harmadikat is!” [A cigányok] nem problémáznak rajta. (Anna, osztályfőnök, interjú)

A lányok itt a kultúrájuk hordozóiként pozicionálódnak (Yuval-Davies 1997), és egy alacsonyabb „kulturáltsági fokon” helyeződnek el, mint a fehér középosztálybeli nők. Ez megjelenik a munkához való feltételezett hozzáállásukban, a reprodukciós mintáikban és az iskolázottsági szintjükben (vö. Dunajeva 2014). Míg én sok olyan cigány lánnyal interjúztam, akik nagyon szerették volna jól megtanulni a szakmájukat és munkát vállalni, Anna itt gyakorlatilag megkérdőjelezi, hogy mennyire érdemes a roma lányokat oktatni, amikor azt mondja, hogy az ő „kulturáltsági fokukon” nem a munkavállalás, hanem a gyerekszülés a cél és norma. Anna a fehér embereket magasan iskolázott, kevés gyereket vállaló középosztálybeliként pozícionálja, a romákat pedig alacsonyan iskolázott, alsó osztálybeli, sok gyereket vállaló emberekként, azzal érvelve, hogy a romák „kulturáltsági fokán” a gyerekszülés életforma, „biológiai elvárás és biológiai rendszer”. A mértéktelenség (ez esetben a mértéktelen reprodukció) az etnicizált/racializált csoportok és az alacsonyabb társadalmi osztályok sajátja a fehér középosztálybeli mércék szerint. Anna egy monolitikus cigány lét vízióját állítja szembe egy monolitikus fehér középosztálybeli „európai vagy észak-amerikai” léttel. Ebben az összehasonlításban a „roma” osztálykategóriává is válik, ahogy a fehérbőrűség

célja volt, hogy az első évben segítsenek a diákoknak letenni az általános iskolai záróvizsgákat, majd két év alatt, a 10. osztály kihagyásával szakmát adjanak a kezükbe. 
is. Az interjúrészlet végén elkezdi mondani, hogy „fehér”, de megáll és kijavítja „nem romára”. Ez arra utal, hogy kolonialista értelemben használja a „fehér” szót, és tudja, hogy ebben az értelemben ez egy rasszista kifejezés. A fehérségről szóló kritikai elméleti megközelítéseket vélhetően nem ismeri, de próbál „politikailag korrekt” nyelvet használni az interjúban.

Anna sokat használja a „kulturális különbség” fogalmát, amikor cigány diákokról beszél. Miközben próbál nem rasszistának tűnni az interjú során, végig érezhetô, hogy számára a „kulturális különbség” hierarchikus „kulturáltsági fokok” közötti különbségtételt jelent magyar és cigány családok között, amelyben a cigányokat „kulturális deficittel” lehet jellemezni (lásd: Kende et al. 2017). Skeggs szerint egy ideje a „kultúra” a „faj/rassz” fogalmát helyettesíti, ami a biológiai esszencializmustól a kulturális esszencializmus felé való eltolódás: „Míg eddig a természetet használták a rasszizmus legitimálására, most a kultúra játssza el ezt a szerepet” (2004, 138; saját fordítás). A „kultúra” diszkurzus jól jön Anna és más tanárok számára, akik tudják, hogy nem szabad rasszista módon beszélni a romákról, de annak nincsenek tudatában, hogy a kultúra koncepcióját oly módon használják, amely újrateremti az etnikai alapú megkülönböztetéseket, ezért az ő „kulturális” diszkurzusuk valójában álcázott rasszizmus.

Az alacsonyabb és magasabb kulturáltsági szintre való hivatkozás az osztály-alapú hierarchia konstruálásának is eszköze ebben az iskolában, amint azt láthattuk korábban az iskolaigazgató gondolataiban a szakiskolás tanulók szexuális kultúrájáról. Anna narratívájában az osztály és etnikum diszkurzusok - amelyek egyben újratermelik a társadalmi egyenlőtlenségeket és az iskolai hierarchiában meglévő pozíciókat is - összeérnek a „kultúra”, „kulturáltsági fok” és „kulturális különbség” fogalmaiban. Butlerrel szólva, ezek a fogalmak olyan diszkurzív helyek, ahol az osztály- és etnikai pozíciók konvergálnak és nem léteznek egymás nélkül (Butler 2005). A cigány és fehér magyar emberek különböző kulturáltsági fokáról szóló magyarázatában Anna összekapcsolja a kulturális és biológiai diszkurzusokat azzal, hogy azt mondja, „ezen a kulturáltsági fokon biológiai elvárás és biológiai rendszer”. Olvasatomban ő arra céloz, hogy különböző kulturáltsági fokokon különböző biológiai rendszerek vannak, vagyis a kultúra meghatározza a biológiai funkciókat, köztük a reprodukciós mintákat. Érdekes érvelés: a kultúra határozza meg a cigányok reprodukcióját, míg a fehérekét az iskolázottsági szint és az anyagi helyzet?

Ha a kultúra és az iskolázottság, ahogy Anna értelmezi őket, ennyire elkülönülnek egymástól, ez talán részben megmagyarázza (legalábbis az ő gondolkodásában), hogy miért „nem éri meg” a cigány lányok szakképzése. Az oktatási intézmény koncepciója magában foglalja a szakmát, a jövőbeli munkát és jövedelmet, a magas kultúrát és a fehérséget. Anna szerint viszont 
a legtöbb cigány lány alulmarad a középfokú oktatás „kulturáltsági fokán” és mindazon, amit ez hozhat az életben, mert sokuk lemorzsolódik, nem tanulja meg a szakmát, korán szül, sok gyereket, és gyermekgondozási segélyen él. Mint korábban felvetettem, az iskolázottsági szint és iskolai teljesítmények erôs összefüggésben állnak a szocio-ökonómiai és családi háttérrel, de ez a korreláció kétirányú: a hátrányos helyzetû és alacsony iskolázottságú családi háttérrel rendelkező fiatalok nagyobb valószínűséggel választanak olyan iskolatípust, ahol alacsonyabb végzettséget szereznek és kevesebb ideig járnak iskolába. Így az alacsony iskolázottság újratermelődik. Az iskoláknak nagy szerepe van az oktatási, és ebből következően a szocio-ökonómiai egyenlőtlenségek újratermelésében (lásd pl. Ball 1993; Bourdieu \& Passeron 1992). Ennek ellenére Anna és más tanárok többnyire úgy beszélnek a szelektív rendszerű iskoláról, mint aminek nincs felelőssége az alacsony végzettség, az alacsony gazdasági-társadalmi státusz, a szûk életkilátások fenntartásában. Mintha mindenért kizárólag a család lenne a felelős, mintha a családi háttér felülírna mindent, amit az iskola elérhet. Ez egy gyakori diszkurzus tanárok körében: amikor azt mondják, hogy az ő feladatuk csak a tantárgyuk megtanítása, a társadalmi reprodukcióban betöltött felelősségüket hárítják.

\section{„Biztos, hogy teljesen ártatlan” - egy magasabb osztály-státuszú cigány lány szubjektum artikulálása}

A következő interjúrészletben megkérdezem Lujzát, aki az egyik gimnáziumi osztály osztályfőnöke, hogy vannak-e cigány tanulók a jelenlegi osztályában. Elmagyarázza, hogy két cigány lány van, az egyikőjük Angliába költözött a családjával, a másik még odajár az osztályba.

Ez a másik kislány, ennek is ugye anyuka otthon van, teljesen tipikus képet mutatnak, ôk egy ilyen nagyon zárt... [...] Na, hát ô az egyik kislány, akire azt mondom, hogy biztos, hogy teljesen ártatlan, mert őt aztán annyira... nagyon jól szituáltak, gazdagok, autóval viszik és hozzák, tehát annyira nem lehet hozzáférni. Tehát ő aztán végképp ilyen, és úgy is engedték el bárhova, hogy apuka külön a lelkemre kötötte, hogy fogom majdnem a kezét, tehát hogy el nem engedem, [...] és kirándulni úgy megyünk, hogy az én szobámban alszik [...]. Különben nagyon helyes, kicsit buta kislány, de nagyon helyes, kedves teremtés, szóval semmi ilyen nincs is. De nagyon jól szituáltak, és anyuka, önálló sofór, meg amit akarunk, tehát ugye gazdagok. De hát ugye azt hiszem, hogy ez már többszörös áttétel, szóval nem most kerültek ki a putriból, hanem már [...] jó régen kikerülhettek, szóval látszik mind a két félen, tehát anyukán is, apukán is. (Lujza, közismereti tárgyakat tanító tanár, interjú) 
Itt a társadalmi nem, az osztály és az etnicitás metszete az eddigiekhez képest szokatlan pozíciót hoz létre az emlegetett cigány lány számára. Mégsem nevezném ezt a megnyilvánulást szubverzívnek a szó butleri értelmében (Butler 2005), mivel dichotóm megkülönböztetést tesz a különböző osztálypozíciójú cigány lányok között, és megerôsíti a magyar-cigány hierarchiát még akkor is, ha ez a bizonyos család feljebb lépett ebben a hierarchiában. A lány története hagyományos patriarchális keretben játszódik: a cigány apuka atyai fennhatóságot gyakorol a lánya szexualitása felett, és megbízza a fehér tanárnőt, hogy vigyázzon a lánya szüzességére azokban a helyzetekben, ahol ô, az apa, nincs jelen. Tehát két, jelentôs hatalommal rendelkezô személy felváltva őrzi a lány „legfőbb kincsét”, elvéve a szexualitása feletti önrendelkezését.

Mint azt korábbi tanulmányomban (Rédai 2016) részletesen elemzem, a lány szüzességének megőrzése a megfelelő partner (férj) megjelenéséig (lásd: Neményi 1999) olyan diszkurzív hely, ahol az etnicitás egy szexualitás diszkurzuson keresztül artikulálódik. Azáltal, hogy az apa a tanárnőre bízza a lánya szüzességének megőrzését, Lujza, a fehér tanár, egyrészt az iskolai etnikai-osztály alapú hierarchia kapuőrévé válik, másrészt egy olyan család tiszteletbeli tagjává, akiknek a gazdagsága elfogadhatóvá teszi a cigányságukat. Ők már, Lujza szemében, nem is „annyira” cigányok, hiszen ,nem most kerültek ki a putriból”. Lujza úgy jellemzi a lányt, mint aki egy „,nagyon helyes, kicsit buta kislány, de nagyon helyes, kedves teremtés, szóval semmi ilyen nincs is”, azaz a lány nem próbálkozik ,illegitim” szexuális kapcsolatokat létesíteni. A család magas anyagi státusza Lujza szemében megkülönbözteti ezt a lányt azoktól a nem gazdag családokból származó cigány lányoktól, akik szexuálisan „túl aktívak”, vulgárisak, kihívóan viselkednek, korán házasodnak és szülnek. Ez a vulgaritás és mértéktelen szexualitás - mint azt korábban is láthattuk - a romák „kultúrájának” részeként artikulálódik, amelyben az osztály és az etnicitás konvergál. Így a lány magasabb osztály-pozíciója egyúttal magasabb etnikai pozíciót is eredményez: ő már „majdnem fehér”. Nem véletlenül, ez a lány a gimnáziumban tanul, ami már eleve egy magasabb pozíciót garantál neki az iskolai hierarchiában.

\section{Konklúzió}

Ebben a tanulmányban szexualitás diszkurzusokat elemeztem, amelyek etnikai és osztály-kategóriákat artikulálnak és egyúttal hozzájárulnak a társadalmi egyenlőtlenségek újratermeléséhez az oktatásban. Az elemzéshez egy többféle iskolatípust egyesítő középiskolában készített interjúk részleteit használtam fel, amelyekben valamilyen formában a diákok szexualitásáról beszéltek tanárok. Nem egy adott hátrányos helyzetű társadalmi csoport 
helyzetét elemeztem interszekcionális szemszögből, hanem olyan diszkurzív helyeket kerestem, ahol a gender, szexualitás, osztály és etnikum metszete létrejön és világos hatalmi pozíciókat jelöl ki (lásd: Butler 2005). Ebben az elméleti és módszertani keretben a társadalmi konstrukciónak a magyar oktatás-szociológiában alig vizsgált aspektusára világítottam rá: arra, hogy hogyan használták a tanárok a diákok szexualitásárólól szóló beszédaktusokat a diákok társadalmi pozíciójának diszkurzív kijelölésére és újratermelésére. Természetesen a tanár-diák nem az egyetlen viszonylat, amelyben diszkurzív reprodukció történik. Máshol vizsgálom a tanár-tanár és diák-diák viszonylatokat is ebből a szemszögből (Rédai 2019). A magyar cigány emberekről szóló friss kutatásokat, amelyek az etnicitás és az osztályhelyzet interszekcióját vizsgálják (lásd: Szombati 2018; Kovai 2017), gazdagítottam azzal, hogy a gender és a szexualitás kategóriáját beemeltem az elemzésbe és megmutattam, hogy a diszkurzív artikulációk hogyan függnek össze a társadalmi egyenlőtlenségek reprodukciójának nagyon is materiális aspektusaival. Emellett reflektáltam a „fehérség” fogalmi kerete használatának fontosságára a cigányság és a cigány-magyar viszonyrendszer vizsgálatában, valamint arra, hogy az „etnikum” és „etnikai” szavak tudományos, közpolitikai és köznyelvi használata nem feltétlenül fedi le, illetve teszi láthatóvá azt, hogy a cigányság diszkurzív (és persze materiális) megkülönböztetése milyen etnikai, rassz-béli és osztály-alapú elemek által artikulálódik. Úgy vélem, a szemléletmódom, amely kritikai diszkurzus-elemzésen keresztül közelít meg társadalmi igazságtalanságokat, és bevonja az elemzésbe az etnicitás és a szexualitás metszeteit is, mintát adhat a gender és a társadalmi osztály-pozíció metszetét középpontba állító materialista feminista megközelítések perspektívájának kiszélesítéséhez.

\section{Felhasznált irodalom}

Ball, Stephen John. 1993. Education. London: Longman.

Berényi, Eszter, Berkovits Balázs \& Erőss Gábor. 2008. „Iskolarendszer és szabad választás - a jóindulatú szegregációról.” In Berényi Eszter, Berkovits Balázs \& Erôss Gábor Az iskolába rendezett gyerek - kiváltság és különbségtétel a közoktatásban. Budapest: Gondolat Kiadó, 11-22.

Bourdieu, Pierre \& Jean-Claude Passeron. 1992. Reproduction in Education, Society and Culture. London: SAGE.

Bourdieu, Pierre. 1984. Distinction. A Social Critique of the Judgement of Taste. Cambridge, MA: Harvard University Press. 
Butler, Judith. 2005. Jelentôs testek. A „szexus” disqłkurzív korlátairól. Ford. Barát Erzsébet \& Sándor Bea. Budapest: Új Mandátum Kiadó.

Butler, Judith. 2001. Problémás nem. Feminizmus és az identitás felforgatása. Ford. Berán Eszter \& Vándor Judit. Budapest: Balassi Kiadó.

Csapó, Benő, Molnár György \& Kinyó László. 2009. „A magyar oktatási rendszer szelektivitása a nemzetközi összehasonlító vizsgálatok eredményeinek tükrében." Iskolakultúra 2009 (3-4): 3-13.

Delgado, Richard \& Jean Stefancic (szerk.). 2001. Critical Race Theory: An Introduction. New York \& London: New York UP.

Downey, Douglas B. \& Dennis J. Condron. 2016. „Fifty years since the Coleman Report: rethinking the relationship between schools and inequality." Sociology of Education 89 (3): 207-220.

Dunajeva, Jekatyerina. 2014. 'Bad Gypsies' and 'Good Roma': Constructing Ethnic and Political Identities through Education in Russia and Hungary. $\mathrm{PhD}$ Doktori értekezés. Kézirat. Eugene: University of Oregon, Department of Political Science.

Federmayer, Éva. 2019. „A hitelesség újraolvasása a kortárs (afro)amerikai irodalomban.” Filológiai Közlöny 65 (2): 40-63.

Foucault, Michel. 1999. A szexualitás története I. A tudás akarása. Budapest: Atlantisz Könyvkiadó.

— 1980. „Two lectures.” In Colin Gordon (ed.) Power/Knowledge. Selected Interviews and Other Writings by Michel Foucault, 1972-1977. New York: Pantheon Books.

Hajdú, Tamás, Kertesi Gábor \& Kézdi Gábor. 2014. „Roma fiatalok a középiskolában. Beszámoló a Tárki Életpálya-felvételének 2006 és 2012 közötti hullámaiból." Budapest Munkagazdaságtani Füzetek, 2014/7. Budapest: Budapesti Corvinus Egyetem \& MTA KRTK, KTI.

Hermann, Zoltán \& Kopasz Marianna. 2018. „Educational policies and the gender gap in test scores: A cross-country analysis." In Budapest Working papers on the labour market, 2018/5. Budapest: MTA KRTK, KTI.

Horn, Dániel. 2009. „Age of selection counts: a cross-country analysis of educational institutions." Educational Research and Evaluation 15 (4): 343-366. 
Horváth, Kata. 2008. „A cigány különbségtétel.” (Textes des doctorants de Mr. Hadas). A CIEH kutatási programjai [Párizs: Université Sorbonne Nouvelle].

Imre, Anikó. 2005. „Whiteness in Post-Socialist Eastern Europe: The Time of the Gypsies, the End of Race." In Alfred J. López (ed.) Postcolonial whiteness: a critical reader on race and empire. Albany: State University of New York Press, 79-102.

Junghaus, Tímea. 2011. „A fehérség kritikai kutatása (Critical Whiteness Studies) I." Tranzitblog.hu.

Kende, Anna, Hadarics Márton \& Barbara Lašticová. 2017. „Anti-Roma attitudes as expressions of dominant social norms in Eastern Europe.” International Journal of Intercultural Relations 60: 12-27.

Kertesi, Gábor \& Kézdi Gábor. 2009. „Általános iskolai szegregáció Magyarországon az ezredforduló után.” Közgazdasági Szemle 56: 959_ 1000 .

Kogan, Irena, Michael Gebel \& Clemens Noelke. 2012. „Educational Systems and Inequalities in Educational Attainment in Central and Eastern European Countries." Studies of Transition States and Societies 4 (1): 6983.

Kovai, Cecília. 2017. A cigány-magyar különbségtétel és a rokonság. Budapest: L'Harmattan.

Központi Statisztikai Hivatal (KSH). 2016. Munkaeröpiaci helyzetteép 2015. Budapest: KSH.

Lareau, Annette \& Elliott B. Weininger. 2003. „Cultural Capital in Educational Research: A Critical Assessment." Theory and Society 32 (56): 567-606.

Liskó, Ilona. 2008. „Szakképzés és lemorzsolódás.” In Fazekas, Károly, Köllő János \& Varga Júlia (szerk.) Zöld könyv a magyar közoktatás megújitásáért. Budapest: ECOSTAT, 95-119.

Lupton, Ruth \& Amelia Hempel-Jorgensen. 2012. „The importance of teaching: pedagogical constraints and possibilities in working-class schools." Journal of Education Policy 27 (5): 601-620.

Mills, Sara. 1997. Discourse. London and New York: Routledge.

Nakayama, Thomas K. \& Robert L. Krizek. 1999. „Whiteness as a Strategic Rhetoric." In Thomas K. Nakayama \& Judith N. Martin (eds.) 
Whiteness: The Communication of Social Identity. Thousand Oaks: Sage Publications, 87-106.

Neményi, Mária \& Vajda Róza. 2014. „Dampened voices: a comparative look at Roma adolescents' discourses on being 'othered' at school." In Szalai Júlia \& Claire Schiff (eds.) Migrant, Roma and post-colonial youth in education across Europe: being visibly 'different'. Houndmills, Basingstoke: Palgrave Macmillan, 103-119.

Neményi, Mária. 2007. „Serdülő roma gyerekek identitás-stratégiái.” Educatio 2007 (1): 84-98.

1999. „Biológia vagy kultúra? Termékenységgel kapcsolatos szerepviselkedések a roma nők körében.” In Kemény István (szerk.) A cigányok. Magyarországon. Budapest: Magyar Tudományos Akadémia, 103-138.

Pfeffer, Fabian T. 2008. „Persistent Inequality in Educational Attainment and its Institutional Context." European Sociological Review 24 (5): 543-565.

Oktatási Hivatal. 2019. PIS A 2018. Összefoglaló jelentés. Budapest: Oktatói Hivatal.

Reay, Diane. 2006. „The zombie stalking English schools: social class and educational inequality." British Journal of Educational Studies 54 (3): 288307.

Rédai, Dorottya. 2019. Exploring Sexuality in Schools. The Intersectional Reproduction of Inequality. London: Palgrave Macmillan.

— 2016. „Etnicitás-konstrukciók a szüzesség és házasság diszkurzusain keresztül." TNTeF 6 (2): 119-149.

Skeggs, Beverley. 1997. Formation of Class and Gender. Becoming Respectable. London \& Thousand Oaks \& New Delhi: SAGE Publications. 2004. Class, Self, Culture. London \& New York: Routledge.

Szombati, Kristóf. 2018. The Revolt of the Provinces: Anti-Gypsyism and Right-Wing Politics in Hungary. New York \& Oxford: Berghahn.

Tóth, Kinga Dóra. 2004. Magyarorşági és angliai kiemelkedett cigányok identitástipusainak összehasonlitó elemzése. PhD Doktori értekezés. Kézirat. Budapesti Közgazdaságtudományi és Államigazgatási Egyetem.

Waters, Mary C. 1990. Ethnic options: choosing identities in America. Berkeley: University of California Press. 
Yuval-Davis, Nira. 1997. Gender and Nation. London \& Thousand Oaks \& New Delhi: SAGE Publications. 